\title{
Explaining Anabaptist Persistence in the Market Economy: Past Paradigms and New Institutional Economics Theory
}

\author{
Martin Lutz ${ }^{1}$ \\ Postdoctoral Researcher and Lecturer \\ Department of History \\ Humboldt University of Berlin
}

\begin{abstract}
Amish and plain Anabaptist economic research has focused either on the religious ethic in the tradition of Weber — religious convictions drive economic behavior — or the ethnic resources model-resources are mobilized to entrepreneurship. Both approaches (1) neglect the greater market context within which the plain Anabaptists have been embedded since the Early Modern Period, and (2) focus primarily on either early Anabaptism or the late 1900s. This article presents New Institutional Economics Theory as an alternative paradigm which understands people's economic behavior by the institutional contexts they are in. It looks at the World War II economy in the United States when many Anabaptist COs applied to be deferred to farm work by arguing that such work is of national importance. It shows that the Amish were thoroughly involved in the modern economy in the 1940s, as Walter Kollmorgen suggests. The Amish also shifted their institutional rules (the Ordnung) in response to larger institutional changes (e.g. wartime America). New Institutional Theory can help scholars better understand how Amish engage in, are shaped by, and shape the larger market.
\end{abstract}

\section{Keywords}

Economic history; Old Order Amish; New institutional economics theory; Market; World War II; Walter Kollmorgen; Elkhart County, IN; Religious ethic; Ethnic entrepreneurship; Weber's Protestent Ethic and the Spirit of Capitalism; Methodenstreit; Civilian Public Service (CPS)

\section{Acknowledgements}

I am grateful for the valuable comments by two reviewers and Cory Anderson's admirable work in making this special volume of JAPAS possible. Rüdiger Bergien has provided important conceptual advice for this paper. David Luthy has helped me extensively in understanding and accessing Amish economic history in the past few years. 


\section{Introduction}

Walter Kollmorgen made it clear in his report that by 1941 the Lancaster County, PA, Amish were not self-sufficient. Particularly in their farming operations, they had become “closely tied up with the market economy” (Kollmorgen 1942, 47). They grew tobacco and corn as cash crops and raised steers and poultry. Selling potatoes, tomatoes, and other vegetables were common; dairy cows and fattening cattle provided additional sources of income. Produce, meat, and dairy products were either sold locally or shipped to urban centers as far as Philadelphia. Ownership of those highly diversified commercial farms was high. While the majority of the Amish worked on the farm, some were full-time craftsmen, operated quarries, or ran repair shops. In short, Kollmorgen portrayed the Amish as active participants in the developed industrial market economy that the United States had become since the late nineteenth century.

Kollmorgen's remark on Amish market integration in 1942 has had a limited impact on the scholarly literature. A number of scholars, particularly in the older literature, argued that the Amish and other conservative Anabaptists were largely self-sufficient and evaded the market economy well into the twentieth century (Bridger, et al. 2001, 75; Redekop, Krahn, and Steiner 1994, vii). Newer economic analyses focus on the economic transformation since the 1970s with the rise of Amish entrepreneurship. They neglect earlier Amish market integration. For example, Kraybill, Johnson-Weiner, and Nolt (2013) state that the "Amish stayed on the sidelines of the American Industrial Revolution for a century (1875-1975) by perpetuating a small-farm lifestyle” (p. 294). Moreover, while the newer literature on the Amish in the modern economy often draws on sociological concepts, a large segment of the literature is not theoretically informed. To sum it up, we know much about Anabaptist theology, social structure, cultural practices, language, persecution and migration, and kinship patterns; we know less about economic development in historical perspective, particularly Amish persistence in the industrialized market economy from the late nineteenth century through the 1970s.

The purpose of this article is therefore twofold. First, it reviews the literature on Amish economic history. Second, it suggests that the adaptation of and connection to wider discourses in economics, economic history, and economic sociology can broaden and deepen our understanding of Amish market integration in the modern economy. New institutional economics theory in particular has been very influential in economic history in recent decades but has been neglected in Anabaptist historiography. I will provide empirical evidence for the 1940s that supports and expands Kollmorgen's claim of Amish market integration. ${ }^{2}$ I argue that there was no transition "from Plows to Profits" (Kraybill and Nolt 2004) in the latter part of the twentieth century. Amish plows had been quite profitable and integrated in the modern market economy before. $^{3}$ 


\section{Literature Review}

A review of the literature on Anabaptist economic history has to take into account the wide variety of Anabaptist groups. Progressive Mennonites of course are very different from the Old Order groups and the Hutterites. Even within each group, we find high variation in social structure and economic practices. To some degree, the economic history of these affiliations has been addressed, as with studies about Mennonite businesspeople and enterprises in the twentieth century (Sharp 2015; Redekop and Redekop 1996; Nafziger 1986, 261-282) and structural patterns of Hutterite economic organization (Peter 1987). Among the Amish, attention has been paid to farm to factory changes beginning in the 1970s - especially in the settlements of ElkhartLaGrange, IN (Meyers 1994); Holmes County, OH (Kreps, Donnermeyer, and Kreps 1994); and Geauga County, OH (Foster 1984) - and to the rise of Amish cottage industries in places such as Conewango Valley, NY (Olshan 1994). That literature is theoretically grounded and methodologically sound. It is, however, more sociological than historical and almost exclusively focuses on the second half of the twentieth century; even John Hostetler's (1963) Amish Society makes only passing mention of Amish market integration and fails to provide empirical evidence beyond Kollmorgen's report (p. 20). Furthermore, this literature assumes that the transition from agriculture to industry and enterprises is synonymous with a transition into the market economy, which is problematic.

Some scholars pursued a genuine interest in economic history in their work. Steven Reschly (2000), for example, focused on a specific region, the Amish in Iowa. He places his work in the context of Pierre Bourdieu' theory of capital and expands it by integrating community as a mediating factor between the individual and society. Gemeinschaft in Ferdinand Tönnies' sense continues to shape Amish economic patterns in modern society, according to Reschly. His analyses of Amish agriculture and the limits of communality have explanatory power for the Amish beyond the narrow regional scope of Iowa. Reschly is, however, much more interested in intra-Amish communal patterns than in their external economic relations with the expanding market economy. Royden Loewen (1993) focused on just that in his study on the market integration of the Mennonite Kleine Gemeinde over the course of three generations between 1850 and 1930. His conceptual framework, however, is not grounded in economic theory. Instead, he uses an eclectic approach following Clifford Geertz's contention that theoretical abstraction in the form of ideal types cannot adequately capture empirical diversity. Jeffrey Longhofer (1993) on the other hand, tried to come to general conclusions based on his analysis of Alexanderwohl Mennonite households in North America. He describes how and explains why "the private household replaced the Mennonite community as the single most important unit through which producers gained access to land" (154). Similar to Reschly, Longhofer focuses on the internal dynamics in the Alexanderwohl Mennonite community. Its external market integration and adaptation to a highly competitive economy are not analyzed but rather taken as given. 
Other studies could be mentioned in this brief overview of literature on Anabaptist economic history (e.g., Janis Thiessen's (2016; 2013) recent books looking at manufacturing Mennonites and the issue of trade unions). That being said, since the 1990s, several scholars have commented on the lack of research on Anabaptist economic history and the application of economic theory. Calvin Redekop (1994) stated in the edited volume on Anabaptist/Mennonite Faith and Economics that it "remains surprising that so little attention has been given to the topic, and so little has been written about the subject” (p. 373). One year later, Steven Nolt (1995) observed that “Amish economic patterns have received little attention” (p. 45). More recently, Theron Schlabach (2007) observed that "[s]urprisingly few authors writing on North American Mennonite History have investigated the influence of market forces on individual and group behaviors” (p. 61), the main exception being research on Mennonite and Amish entrepreneurship. The vast majority of that literature, however, focuses on recent, late-twentieth century developments and is much more influenced by sociology than economic theory. Many fewer studies in Anabaptist economic history predate the 1970s, and even the few that exist have rather shallow theoretical grounding.

I will next briefly summarize the substantial literature on economic history on early Anabaptism. Thereafter, I will reconstruct the general scholarly discourse as a development from a paradigm of religious ethic to a paradigm of ethnicity.

\section{Early Modern History}

Scholars have had substantial interest in the economics of sixteenth century Anabaptism. Hutterite communal ownership_-its theological grounding and resulting economic practicesare well researched (Fretz 1963; Klassen 1964; Friedmann 1956; Gross 1980) as is Anabaptist economic success, for example, Mary Sprunger's (1994) work on merchants in the Netherlands, or Jean Séguys (1973) studies on Anabaptist agriculture. Many of those studies are empirically sound theoretical reflections and applications of analytical concepts; however, they lack the particularly rich methodological toolbox of new institutionalism. While we learn much about spiritual/religious impacts on economics - important individuals and events, the suffering and persecution of Anabaptists - we learn less about institutions, path-dependencies and breaks, social class and hierarchy, labor and management, investments, production and consumption, and exchange. The dominant theme is the Anabaptist economic separation from the world, their selfreliance and self-sufficiency in times of persecution, and their persistence at the fringes of mainstream society. What is missing is an analysis not of separation but integration in the emerging European market economy.

\section{The Old Paradigm: Religious Ethic and Economic Development}

How have researchers interpreted the structural patterns of Anabaptist economic practices? Common to the literature summarized above is its focus on religious ethic: theological convictions influenced the way the early Anabaptist structured their economic activity. This 
explanatory approach is very much in line with Max Weber's writings on the Protestant ethic and the spirit of capitalism (Marshall 1982; Weber [1958] 2003). Weber argued that values — such as a hard work ethic, thrift, and strategic accumulation of capital in Protestant denominations, Calvinism in particular - transformed the Northern European economy, leading to modern capitalism. The major difference between Weber's Protestants and Anabaptists is that the latter did not turn into protagonists of modern capitalism and industrialization (Appling 1975). However, Anabaptists worked hard, were thrifty, and represented the ascetic lifestyle that we know from Weber's writings. I call this explanatory model of religious ethic "the old paradigm.” It was widely used in the scholarly literature well into the second half of the twentieth century (Nafziger 1986, 265; Peter 1987; Peters 1994; Halteman 2014, 265).

\section{The New Paradigm: Ethnic Resources and Economic Development}

In the second half of the twentieth century, researchers shifted their analytical focus away from religious ethic. Applying ethnographic analysis, studies looked at social structures and economic practices in methodologically innovative ways, providing insight into the social and economic developments in the 1960s and 1970s, e.g. for the Amish in Lancaster County (Tank 1979) and the Hutterites in Manitoba (Ryan 1977). This strand of research took off in the 1990s against the background of an unprecedented rise in Amish entrepreneurship, particularly in densely populated southeastern Pennsylvania. Ethnicity became a major analytical focus to explain this phenomenal rise of Anabaptist business (Kraybill and Nolt 2004; Kraybill, Nolt, and Wesner 2010). An ethnic community "refers to the values, norms, rituals, social networks, and customary practices of a particular ethnic group.” That is, ethnicity and religion are different sides of the same coin: "It is impossible to separate religion from ethnicity in Amish society [...]” (Kraybill, Nolt, and Wesner 2010, 5). Based on a sociological model, Kraybill, Nolt, and Wesner argue that the ethnic community produces certain resources than foster and sustain Amish entrepreneurship. Social trust is one key category that accounts for Amish business success. Ethnicity as an analytical concept has had a tremendous influence in Anabaptist studies beyond Amish entrepreneurship research; it can be considered the new paradigm in Anabaptist economic history. Its most important contribution is that it added complexity to the debate. Amish and other Anabaptist economic practices are not just shaped by their religious ethic as the older paradigm argued. Ethnic resources such as culture, kinship, language, and the perception of a common heritage are as important for Anabaptist economic practices as religious ethic.

\section{Lessons from the Literature}

This short review is far from extensive; nevertheless, it shows important patterns in Anabaptist economics research. In recent years, scholarly work on Amish entrepreneurship has seen a tremendous surge. The majority of that literature focuses on the late twentieth century. We now have good overviews of the fundamental changes in Amish economic practices in North America. Some, but not all, of those studies are theoretically informed and relate to wider 
discourses on modernity/modernization, ethnicity/ethnic entrepreneurship, and technology. This is a tremendous achievement. Nonetheless, there are still gaps in the literature.

Notably, the economic history of the Amish in the nineteenth and early twentieth centuries is still under-researched. For example, little research has investigated how the Amish adjusted to the Great Depression when agricultural prices plummeted, and even then, this small body of literature focuses on Anabaptist separation from, not their integration with, the majority society. The emphasis is explaining how the Anabaptists have survived the industrial revolution despite their separation, not because of their integration in the market economy. There is a lack of systematic comparative studies that (a) analyze economic structures and practices of different Anabaptist communities and (b) relate Anabaptist economic developments to other groups in general society. The recent paradigmatic shift in history towards transnational and global analysis has had only a minor impact on Anabaptist studies.

Moreover, the new paradigmatic focus on Amish ethnicity has its drawbacks. Its primary goal is to explain how communal resources promote entrepreneurship and sustain ethnic communities. It has often been applied to account for separation of minority groups from mainstream society, not their integration; indeed, eminent sociologist Alejandro Portes coined the term "ethnic enclave” to represent the separation of an ethnic group from the majority society. This analytical focus on the enclave might lead scholars to focus too much on the intracommunal perspective and neglect the economic relations and transactions with the extracommunal world. That is important for historical analysis of the Amish who-as market players-have to relate to non-Amish in economic transactions. Also problematic is applying the ethnic approach to Amish economic history prior to the 1970s. The rise of Amish entrepreneurship is a distinctly recent phenomenon that began in the latter twentieth century.

\section{Why Institutions Matter}

To arrive at the theoretical alternative I propose-new institutional economics theory-I will now leave the scholarly discourse on Amish economic history for a few pages and turn to a debate that took place in the German-Austrian academic world in the late nineteenth century. There were two main protagonists in this Methodenstreit or "battle of the methods," which sociologist Gordon Marshall (1982) covers in The Search of the Spirit of Capitalism.

\section{The "Battle of the Methods"}

One, Gustav von Schmoller, represented the German Historical School of Economics at the universities in Halle, Straßburg, and eventually Berlin. Von Schmoller and the Historical School fought the emerging Neoclassical School of economics developed by scholars such as Alfred Marshall, John Bates, and Léon Walras. The Neoclassical school established economics as an unhistorical, abstract, mathematical discipline based on the assumption of rational choice and universal laws that could be deduced to explain specific phenomena. In contrast, von Schmoller argued for an approach that rested on three major pillars. First, economic behavior is 
not driven by narrow economic interests. On the contrary, individuals are influenced by a number of other factors, such as ethics. Second, economic choices were not independent of time and place as the Neoclassical School suggested. Rather, they are influenced by their specific political, legal, cultural, and social context. In other words, economic action is not universal and independent of time and space but specific to its context. Third, von Schmoller pursued an inductive approach as opposed to the Neoclassical School's deductive approach. Empirical observation had to come before theoretical deduction.

While the Historical School was first established as a response to the Neoclassical School of economics, it was soon confronted with a powerful opponent in Vienna. Carl Menger, proponent of the Austrian School of economics, published his book The Errors of Historicism in German Economics, where he radically attacked von Schmoller and his associates. Their empiricist, case-by-case approach focused on singular historical settings was all wrong, according to Menger. What epistemological gain would the Wissenschaft get from this? Menger argued that if

economic history [...] is to be completed in the spirit of Schmoller's historical micrography - one only has to think of the prices of meat of Elberfeld! of Pforzheim! of Mühlheim! of Hildesheim! of Germersheim, of Zwickau! and so on - only eons would suffice. Like the astronomers who had to introduce the concept of light years into their science to calculate their vast distances, we as economists would have to begin counting in the periods of life of solar systems in order to get an estimate of how long it would take to develop a complete historical-statistical foundation for the theoretical research Schmoller envisions. (Menger 1884, 38-39) ${ }^{4}$

In Menger's eyes, only a theoretically grounded, deductive, and generalizing approach could possibly deal with the infinite complexity of the real world. Von Schmoller's inductive, case-bycase approach would lead to nothing.

The Methodenstreit was fought long ago but its impact is still highly relevant today. The Historical School and its inductive, empiricist approach died a quick death in the early 1900s. The Neoclassical School became the dominant paradigm in economics and enshrined its theoretically deductive, quantitative, and mathematical approach. The recent public and scholarly debate about its shortcomings have been voiced particularly since the 2008 financial crash and ensuing economic downturn.

However, there was another voice in the Methodenstreit that is often overlooked. That voice was Max Weber, who had been trained as an economist, a Nationalökonom, and became one of the leading figures in establishing sociology as an academic discipline in the late nineteenth and early twentieth centuries. In 1904/05 he published two essays on the Protestant ethic and the spirit of capitalism, which have become almost synonymous with a cultural approach to explain the rise of modern capitalism with a huge impact through the present academic debate (Weber 2003[1958]). Less known is Weber's initial intention behind the two essays and his related work. As Marshall (1982) shows, Weber's research has to be interpreted as 
an "intervention" in the Methodenstreit, where he argued for a middle ground. On the one hand, Weber agreed with Menger that the empiricist approach of the Historical School resulted in endless case studies without any theoretical framework to tie them together. The Austrian and Neoclassical Schools, on the other hand, had gone way too far in the other direction, of creating abstract models without any consideration of phenomena in the real world.

Weber then suggested a third way of bridging the gap between theory and empiricism by using ideal types. Ideal types are constructed concepts that are based on empirical observations and accentuate them in order to capture more than just a specific unique phenomenon. An ideal type in that sense is a model

formed by the one-sided accentuation of one or more points of view and by the synthesis of a great many diffuse, discrete, more or less present and occasionally absent concrete individual phenomena, which are arranged according to those onesidedly emphasized viewpoints into a unified analytical construct. (Weber 1949, 90)

As important as the concept of ideal types is, Weber's more general assertion is that the conditions of a given society influence economic developments-not just cultural factors such as religion but also political, legal, and social conditions pre-structure the way how humans engage in economic activity (Ghosh 2008). Any analysis of economic history has to take into account the historically specific and, in that sense, unique conditions that shape the actions of merchants, entrepreneurs, community members, or a nation. It is precisely the combination of the stylized, abstract ideal type and the importance of historical specificity that are at the core of Weber's intervention in the Methodenstreit. In that respect, a number of scholars have argued to interpret his work not just with regards to the role of religion in modernization processes but to consider him as an early proponent of institutionalist theory (Richter 2005; Swedberg 2008; Maurer 2007).

\section{From the Methodenstreit to New Institutional Economics Theory}

Weber's ideas experienced the fate of the German Historical School in economics. They were crowded out by the mathematically oriented Neoclassical School who had no interest in the question of how institutions shape economic development. Only in the 1970s, a new paradigm called new institutional economics started gaining influence in economics and economic history. As Weber had done, this paradigm focuses on the influence of legal, political, social, and cultural institutions on economic developments. Institutions are considered the "rules of the game" that shape economic choices (North 1990, 3). Institutions can be formal, such as a society’s political system or legal framework. They can also be informal, such as peoples' cultural norms or the belief system. According to this theory, people try to pursue their self-interest based on their preferences, motivations, and interests. If, for example, an entrepreneur forwent a potentially lucrative deal because of moral convictions, that would be a perfectly rational and therefore predictable choice within the institutionalist framework. 
In sociology, Weber survived and became a major reference point in Germany and also in the English-speaking academic world after Talcott Parsons translated parts of his work in the 1930s. Contemporary sociology, therefore, owes a great deal to Weber. That is particularly true for the New Economic Sociology (Swedberg 2000; Nee and Swedberg 2007; Maurer 2010). New Economic Sociology is an institutionalist approach explaining how people engage in economic action. Both new institutional economics and new economic sociology are based on empirical research but go far beyond description of contemporary or historical events. Both approaches try to relate phenomena to each other across time and uncover structural patterns, be it institutional change or continuity. The central epistemological question in institutional theory is not a descriptive "what" but an explanatory "why” and "how." Institutionalist scholars try to identify correlations and causations in historical developments. They aim to build explanatory models that are empirically valid when applied to specific case studies and can explain larger structural developments.

For example, the late economic historian and Nobel laureate Douglass North devoted his entire career to the analysis of economic institutions and the special development of Western Europe and North America from the Middle Ages to modern times (Wallis 2016; North 1981). In his and other scholars' work, micro- and macro-level analysis is applied to the study of corporations, markets, the state, non-state actors such as associations and churches, informal trading networks, and more. While North's older publications focused on the rule of law and property rights as primary drivers of economic development, his later work stressed cultural factors, such as actors’ belief systems, for economic institutions (North 2005).

\section{New Institutional Economics Theory and the Amish}

There is a substantial literature on Anabaptist economic development. Given the frequently difficult access to primary sources or interview participants, I certainly do not want to downplay this achievement. At the same time, to paraphrase Carl Menger, if Anabaptist economic history would continue with such an empiricist, case by case study approach-one only has to think of the Ordnung of an Amish community in Holmes County, or the crops planted by Old Order Mennonites in upstate New York, or an industrial Hutterite colony in Manitoba, and so on - microanalysis would be infinite considering the wide variety of Anabaptist communities and their constant changes. It the past 20 years, new institutional theory has evolved into a highly sophisticated framework that is applied across the spectrum of economic history. The analysis of religious institutions and their economic impact in particular has become a vibrant field of interdisciplinary debate (Kuran 2011; Barro and McCleary 2003; Lutz 2017). Studies on the economic history of the Amish and other Anabaptist groups are almost entirely absent in this literature.

How can institutional theory contribute to the analysis of Anabaptist economic history? New institutional theory offers a conceptual language that allows for communication between scholars in wider academic discourses. Anabaptist economic history is a fascinating field for 
research that has potential to contribute to current debates in general economic history. How secular is the modern economy? How do religious actors engage in and possibly shape the market? How do communities that differ significantly from corporate hierarchies respond to economic development? How resilient are they in times of globalization, de-globalization, nationalism, the war economy, economic crises, and rapid innovation? How efficient and effective is their communal division of labor and management? Many more questions could be asked but the answers would have to be understood also by a wider circle of scholars. The application of theoretical and methodological tools from economics and economic history would allow for abstraction and provide such a conceptual language for further scholarly communication.

More theoretically informed research would allow for systematic comparison between Anabaptists and other social groups. There is an increasing scholarly interest within economic history in religion, with a particular focus on Islam and religious minorities in a global perspective. The Amish, while being specific in many ways, are certainly not the only religious group that engages in the modern economy. Comparative analysis of similarities and differences with other communities might give us a much better picture of how religious groups succeed or fail in the modern economy and highlight structural patterns that so far have been overlooked. Closer reception of and collaboration with these strands of research can thus be beneficial for scholars of Amish economic history. In the next section, I will give an empirical example of the approach being applied to Amish involvement in the American World War II economy.

\section{The Amish in the World War II Economy}

On January 25, 1943, Colonel Lewis F. Kosch, director of camp operations in the Selective Service System under General Lewis B. Hershey (Krehbiel 2011), received an appeal from Ezra Bontrager from Elkhart County, IL. ${ }^{5}$ Bontrager was a 20-year old conscientious objector who, upon his draft in 1941, had listed his occupation as a feed mill worker and his church affiliation as “Old Order Amish Mennonite."6 He had been classified in the 4-E category and assigned to work at the Civilian Public Service (CPS) camp in Bolton, MO. This category allowed conscientious objectors to evade combatant and non-combatant military service but required them to work on projects of national importance. Bontrager now applied to be released from his CPS camp and be changed to 2-C classification, which would allow him to defer service entirely because of an agricultural occupation. Attached to the appeal were letters by his former employer Simon Bontrager and three neighboring broiler producers from the Clinton district, Fred Kauffman, Sanford Eash, and Daniel Bontrager. All four requested that Ezra Bontrager be released from Civilian Public Serve so he could return to his feed mill job and function in the local economy.

How does this incident fit into our knowledge about Amish economic history? The beginning of World War II induced rapid economic growth in the United States, particularly after the country entered the war in 1941 (Hughes and Cain 2011, 525). This is particularly evident when looking at agriculture. The war created a high demand for agricultural products while at the 
same time it severely reduced the supply of labor. Additionally, the war created an atmosphere of patriotic fervor. Government policies and public discourse demanded that every economic sector contribute to the war effort, thereby creating new expectations as to what constituted legitimacy in the economic field. Ezra Bontrager's appeal to be released from Civilian Public Service thus has to be analyzed with the changing societal expectations toward the national economy in mind.

Civilian Public Service was established in 1941 with heavy involvement of Anabaptist and other peace churches. ${ }^{7}$ It allowed conscientious objectors between 1941 and 1947 to work on projects of "national importance" as an alternative to combatant and non-combatant military service. There were other options, such as the 2-C classification that allowed men in agricultural occupations to remain in or return to their former jobs. Many Anabaptist conscientious objectors tried to obtain a 2-C classification so they could work on their family farms. In order to be classified in this category, the applicant had to prove that his occupation was vital in the sense that it complied with the requirements of the draft board. The legitimacy of the applicant's work for the national economic war effort thus became crucial for obtaining a 2-C classification. Let us now take a look at the legitimization strategies in Bontrager's case.

Ezra Bontrager kept his application short. He formally applied for his transfer to the 2-C classification and then referred to the enclosed letters for further explanation and justification. The four letters emphasized the importance of the Clinton Center Mill in supplying feeds for local farmers. A nearby mill had closed due to the shortage of labor, so Simon Bontrager argued it was even more important that Ezra return to his work. ${ }^{8}$ Daniel S. Bontrager reminded Kosch of the special circumstances and "[in] this present war Crisis our Government has recognized the importance of the production of food, and has urged the farmers to produce to the utmost." ${ }^{\text {"9 }}$ In a similar way, Fred S. Kauffman wrote that the mill had a "vital, essentatial [sic.] part in the prosecution [sic., probably production/execution] of our farm program" and that it "should have at least equal consideration in securing and holding their hired help as is given other essential businesses." ${ }^{, 10}$ Despite these arguments, Ezra Bontrager's application was futile. Colonel Kosch decided that the conditions for release were not apparent. He did not specify the reasons but it might be that a feed mill job did not qualify as an agricultural occupation necessary for a 2-C classification. Bontrager was not discharged from CPS service until January 1946 after the war had ended. Nevertheless, the case shows the legitimization strategy used: Ezra's occupation as a feed mill worker was essential for the national economic effort, as the local Amish farmers were well integrated into the economy in supplying food for the market.

Other Anabaptist conscientious objectors were more successful than Ezra Bontrager, as the extensive records of the Civilian Public Service System at the National Archives II in College Park, MD, show. ${ }^{11}$ One example is another "Amish Mennonite" conscientious objector, the farmer Ammon J. Bontrager from LaGrange County, IN. ${ }^{12}$ In May 1943, he applied to be released from his CPS camp at Well Tannery, PA, so he could return home to work on his ailing father's farm of 120 acres. Attached to the application was a detailed description of the crops cultivated and livestock raised on the farm. Each entry was converted into the war units as 
classified by the Selective Service and War Man Power Commission to determine whether the applicant could prove his contribution to the war economy and be released from service. Bontrager's farm received a total of 28.03 war units, almost double of the war unit objective set by the commission. Attached was a letter by a local doctor certifying that Bontrager's father was physically unfit to operate the farm by himself and needed help. That information sufficed. On March 19, 1944, Ammon Bontrager was discharged from service. His success was not an exception. Many other Anabaptist conscientious objectors were able to obtain a 2-C classification. In each case, the applicant's legitimization strategy rested on his importance for the national war effort. In each case, the "war unit" objective allowed for a transparent classification of the conscientious objector's economic utility.

\section{Discussion: The Bontragers and New Institutional Theory}

How can we interpret Ezra Bontrager's, Ammon Borntrager's, and thousands of other Anabaptists' cases in the context of the United States war economy? And why and how could new institutional theory be useful? My answers will not be comprehensive but sketch theoretical ideas that are developed as part of an ongoing research project.

Historiography of Anabaptists during World War II has focused primarily on the religious aspects of conscientious objection, the contribution of Anabaptists to the management of the CPS camps, and the long-term impact of the Selective Service on communal structures (Gingerich 1949; Keim, Stoltzfus, and Kelley 1988). Economic issues, such as government intervention in the private sector, the rapid expansion of both industry, and agricultural production and labor shortage have rarely been addressed. In addition, the existing explanatory models do not suffice to explain Amish strategies in the World War II economy. The old paradigm (religious ethic influences how the Amish engage in economic activity) would suggest that the Amish entirely refrain from C-2 applications as participation in the "war unit” objective went against fundamental Anabaptist beliefs. The new paradigm (the Amish mobilize ethnic resources for entrepreneurship) also has limited explanatory power in this case, as Amish ethnic entrepreneurship was largely absent in the 1940s. The Amish were confronted with massive public and government discrimination with regards to schooling, a public and private modernization ideology that favored industrial mass production and mechanized agriculture, and widespread anti-German sentiment. Both paradigms thus have limited explanatory power when we try to understand Amish strategies in the World War II economy.

Institutional theorists have developed an approach coined neo-institutionalism to address the relationship of societal expectations and the economic field. Neo-institutionalists argue that actors need to justify their economic actions vis-á-vis the expectations and requirements of their societal environment. On the one hand, compliance with those expectations adds legitimacy to the actor's behavior. Deviation from societal rules, on the other hand, can become costly, for example, as a result of government regulation targeted at the actor's supposed illegitimate behavior. In the Amish context, the institutional "rules of the game” prescribed by the Ordnung 
were acceptable as long as they did not deviate from public and government expectations. As those expectations changed in the context of World War II, the Amish were confronted with the question of whether to entirely reject the requirements of the war economy or partially comply with changed expectations in order to legitimize their own actions.

Bontrager and other Amish COs show the importance of that legitimacy. Anabaptists who appealed to be released from CPS did so by emphasizing their contribution to the national economy. They referred to the productivity of their family farms or the importance of their other occupations, emphasizing the legitimacy of their work under the circumstances of the war. It is striking how the records show the Anabaptists trying to appear not as "the other" but as normal economic actors in that they played by the institutional rules, not against them. For example, Amish references to the lack of certain types of modern farm equipment as a reason for a 2-C classification are remarkably absent. Market integration, or rather Anabaptist contribution to the existing economic system, was used as an argument to appeal for certain privileges granted by the selective service system.

The Selective Service System records provide extensive evidence of Amish economic activity. The National Archives holds case files of the almost 12,000 conscientious objectors during World War II. Among those were hundreds of Amish. Some of these records are short and include only the standard selective service questionnaire and administrative correspondence. Others are extensive and include a wide variety of documents. Particularly important for economic historians is the extensive information about their economic situation. The questionnaires required information on farm size and acreage devoted to specific crops, livestock, the applicants' educational background, occupation, income, and more. The Amish as registered and rated by the Selective Service System appear as a productive people in the context of the World War II economy, with their profitable plows and non-farming occupations.

\section{Conclusions}

This article fist reviewed the historiographic literature on Anabaptist economic history with a focus on the Amish. The old paradigm focused on the religious ethic of hard work, asceticism, and thrift, in the tradition of Max Weber's argument that values produce economic systems. The newer paradigm uses ethnicity-e.g. language, cultural practices, and social trustas an additional explanatory variable for Amish economic behavior. This article then identified a gap in the literature concerning Amish economic history in the late nineteenth and early twentieth centuries. This gap refers to theoretically informed and empirically systematic studies. Amish economic history is under-researched compared to other areas of research such as theology, kinship, or migration.

Amish and plain Anabaptist studies rarely draws on theoretical and methodological debates in the wider field of economics and economic history. New institutionalism, in particular, is a powerful paradigm that transcends several academic disciplines, including economic history, 
economic sociology, and political economics (Steinmo 2001). So far, Amish and plain Anabaptist studies has almost completely ignored it. That is somewhat surprising, as its tools are highly applicable to Anabaptist economic history research. New institutional economics is concerned with the "rules of the game" that structure economic activity. Institutionalist research on the Ordnung, for example, could yield enormous empirical results regarding economic efficiency or inefficiency, the amount of transaction costs required to uphold a specific Ordnung, or the transparency of information in principal-agent relationships. Similarly, sociological institutionalism's focus on the legitimacy of institutions could be fruitful. It asks questions such as why certain people consider a given institutional arrangement as legitimate while others pursue institutional change. Amish and plain Anabaptist studies might hugely benefit from such an institutionally informed research agenda. For example, a plethora of studies exists on the role of trust in economic relations, the cultural constraints and incentives of market integration, and the resilience of economic actors in times of crises. Those studies might open new and comparative perspectives. At the same time, Amish and plain Anabaptist studies could contribute a wealth of empirical findings to a major discourse in economic history, such as the debate on the varieties of capitalism in the modern economy (Coates 2005; Hall and Soskice 2001).

The market as a platform of exchange and the development of the modern market economy in the nineteenth century should be more prominent in Amish and plain Anabaptist studies. The railroads had created national markets in North America and the steamship contributed to a rapidly globalizing economy. How did economic globalization, and deglobalization after 1914, influence Anabaptist economics? To what degree did Anabaptists adapt to changes in the market and possibly even shape markets? Much of the existing literature is focused on Amish "separation from the world.” But Walter Kollmorgen considered the Amish as market players. Despite their peculiarities in terms of culture, social structure, and practice, he regarded them as active participants in the industrialized economy. I suggest that we take Kollmorgen's observation seriously. The Bontragers are just two examples of the Amish involvement in the World War II economy. More generally, scholars should pay close attention to the Amish in the modern economy and apply relevant theories such as new institutionalism.

\section{Endnote}

${ }^{1}$ Contact information: Martin Lutz, Unter den Linden 6, 10099 Berlin, Germany; +49 (0) 30 2093 70574; martin.lutz@hu-berlin.de

${ }^{2}$ This article is part of an ongoing research project on Anabaptist economic history in the nineteenth and twentieth centuries. The evidence presented here is a small sample of a much larger body of primary sources used in the study.

${ }^{3}$ Kraybill, Johnson-Weiner, and Nolt (2013) briefly comment on Amish integration in local markets in the late nineteenth century. However, due to railroads, telegraphs, transcontinental shipping, and a massive rise in international trade, local markets were already deeply tied to a 
global—or at least transatlantic_-economy, particular in grain markets (O'Rourke and Williamson 1999). That means grain prices in Antwerp or Liverpool, two of the largest European import hubs for North American grain, had a direct impact on local prices in rural Pennsylvania.

${ }^{4}$ Translated from German into English by Jasper Stange.

${ }^{5}$ Correspondence between Ezra Bontrager and Colonel Lewis F. Kosch, January 19, 1943, National Archive II, RG 147 Entry 17, Selective Service System Conscientious Objectors Personnel Folders (1940-1947), box 197.

${ }^{6}$ Questionnaire from Conscientious Objector Report of Ezra Bontrager, National Archive II, RG 147 Entry 17, Selective Service System Conscientious Objectors Personnel Folders (1940-1947), box 197.

${ }^{7}$ Website of CPS, http://civilianpublicservice.org/, last visit: 29 June 2017.

${ }^{8}$ Correspondence between Simon Bontrager and Wilbert Nafziger, National Archive II, RG 147 Entry 17, Selective Service System Conscientious Objectors Personnel Folders (1940-1947), box 197.

${ }^{9}$ Letter from Daniel S. Bontrager to Wilbert Nafziger, National Archive II, RG 147 Entry 17, Selective Service System Conscientious Objectors Personnel Folders (1940-1947), box 197.

${ }^{10}$ Letter of Fred S. Kauffman, National Archive II, RG 147 Entry 17, Selective Service System Conscientious Objectors Personnel Folders (1940-1947), box 197.

${ }^{11}$ So far, I have only looked at a small sample of cases. By way of the COs, it is possible to give a comprehensive quantitative overview of Anabaptist economic activity. It is also possible to analyze economic networks, the functioning of economic networks, the distribution of property, educational attainment, etc. Moreover, the very extensive and detailed documentation in some case files allows for qualitative analysis of Anabaptist perceptions of the economy, their contribution to it, problems and conflicts, and institutional arrangements governing the complex interaction between the individuals and their communities with the market.

12 Letter from Ammon J. Bontrager, National Archive II, RG 147 Entry 17, Selective Service System Conscientious Objectors Personnel Folders (1940-1947), box 197.

\section{References}

Appling, Gregory. 1975. “Amish Protestantism and the Spirit of Capitalism.” Cornell Journal of Social Relations 10:239-50.

Barro, Robert, and Rachel McCleary. 2003. "Religion and Economic Growth across Countries.” American Sociological Review 68(5):760-81. https://doi.org/10.2307/1519761

Bridger, Jeffrey, Al Luloff, Louis Ploch, and Jennifer Steele. 2001. "Fifty-Year Overview of Persistence and Change in an Old Order Amish Community.” Journal of the Community Development Society 32(1):65-87. https://doi.org/10.1080/15575330109489693 
Coates, David (ed.). 2005. Varieties of Capitalism, Varieties of Approaches. Basingstoke, Hampshire: Palgrave Macmillan. https://doi.org/10.1057/9780230522725

Foster, Thomas. 1984. "Occupational Differentiation and Change in an Ohio Amish Settlement.” The Ohio Journal of Science 84(3):74-81.

Fretz, Winfield. 1963. “Bruderschaft und ökonomische Ethik der Täufer.” Pp. 187-93 In Das Täufertum: Erbe und Verpflichtung, edited by Guy Hershberger. Die Kirchen der Welt Reihe B, Band II. Stuttgart, Germany: Evangelisches Verlagswerk.

Friedmann, Robert. 1956. “Economic Aspects of Early Hutterite Life.” Mennonite Quarterly Review 30(4):259-66.

Ghosh, Peter. 2008. A Historian Reads Max Weber: Essays on the Protestant Ethic. Kultur- und sozialwissenschaftliche Studien 1. Wiesbaden, Germany: Harrassowitz Verlag.Halteman

Gingerich, Melvin. 1949 Service for Peace: A History of Mennonite Civilian Public Service. Akron, PA: Herald Press.

Gross, Leonard. 1980. The Golden Years of the Hutterites: The Witness and Thought of the Communal Moravian Anabaptists During the Walpot Era, 1565-1578. Scottdale, PA: Herald Press.

Hall, Peter, and David Soskice (eds.). 2001. Varieties of Capitalism: The Institutional Foundations of Comparative Advantage. Oxford, UK: Oxford University Press. https://doi.org/10.1093/0199247757.001.0001

Halteman, James. 2014. “Anabaptist Approaches to Economics.” Pp. 245-62 in The Oxford Handbook of Christianity and Economics edited by Paul Oslington. Oxford, UK: Oxford University Press.

Hostetler, John. 1963. Amish Society. Baltimore, MD: Johns Hopkins University Press.

Hughes, Jonathan, and Louis Cain. 2011. American Economic History, 8th ed. Boston, MA: Addison-Wesley.

Keim, Albert, Grant Stoltzfus, and Dean Kelley. 1988. The Politics of Conscience: The Historic Peace Churches and America at War, 1917-1955. Scottdale, PA: Herald Press.

Klassen, Peter. 1964. The Economics of Anabaptism: 1525-1560. London, UK: Mouton \& Co. Kollmorgen, Walter. 1942. Culture of a Contemporary Rural Community: The Old Order Amish of Lancaster, Pennsylvania. Washington, D.C.

Kraybill, Donald, Karen Johnson-Weiner, and Steven Nolt. 2013. The Amish. Baltimore, MD: Johns Hopkins University Press.

Kraybill, Donald, and Steven Nolt. 2004. Amish Enterprise: From Plows to Profits, $2^{\text {nd }}$ ed. Baltimore, MD Johns Hopkins University Press. 
Kraybill, Donald, Steven Nolt, and Erik Wesner. 2010. “Amish Enterprise: Khe Collective Power of Ethnic Entrepreneurship.” Global Business and Economics Review 12(1/2):3-20. https://doi.org/10.1504/GBER.2010.032315

Kreps, George, Joseph Donnermeyer, and Marty Kreps. 1994. “The Changing Occupational Structure of Amish Males.” Rural Sociology 59(4):70-19. https://doi.org/10.1111/j.15490831.1994.tb00556.x

Kuran, Timur. 2011. The Long Divergence: How Islamic Law Held Back the Middle East. Princeton, NJ: Princeton University Press.

Loewen, Royden. 1993. Family, Church, and Market: A Mennonite Community in the Old and the New Worlds, 1850-1930. Toronto, ON: University of Toronto Press.

Longhofer, Jeffrey. 1993. "Household and Community: The Alexanderwohl Mennonites and Two Counterfactuals, the Amish and Hutterites.” Research in Economic Anthropology 14:153-88.

Lutz, Martin. 2017. "Religion und Wirtschaft.” In Handbuch Religionssoziologie edited by Volkhard Krech, Detlef Pollack, Markus Hero, and Olaf Müller. Wiesbaden, Germany: Springer.

Marshall, Gordon. 1982. In Search of the Spirit of Capitalism: An Essay on Max Weber's Protestant Ethic Thesis. London, UK: Hutchinson.

Maurer, Andrea. 2007. “Der Geist des Kapitalismus - Eine institutionentheoretische Interpretation der Protestantischen Ethik.” Pp. 63-88 in Ökonomie und Religion edited by Martin Held, Gisela Kubon-Gilke, and Richard Sturn. Marburg, Germany: Metropolis.

— (ed.). 2010. Wirtschaftssoziologie nach Max Weber. VS Verlag für Sozialwissenschaften.

Menger, Carl. 1884. Die Irrthümer des Historismus in der deutschen Nationalökonomie. Wien.

Meyers, Thomas. 1994. "Lunch Pails and Factories.” Pp. 165-181 in The Amish Struggle with Modernity edited by Donald Kraybill and Marc Olshan. Hanover, NH: University Press of New England.

Nafziger, E. Wayne. 1986. Entrepreneurship, Equity, and Economic Development. Greenwich: Jai Press.

Nee, Victor, and Richard Swedberg (eds.). 2007. On Capitalism. Stanford, CA: Stanford University Press.

Nolt, Steven. 1995. "The Rise and Fall of an Amish Distillery: Econmic Networks and Entrepreneurial Risk on the Illinois Frontier.” Illinois Mennonite Heritage 22(3):45-63.

North, Douglass. 2005. Understanding the Process of Economic Change. Princeton, NJ: Princeton University Press. https://doi.org/10.1515/9781400829484

North, Douglass. 1990. Institutions, Institutional Change and Economic Performance. Cambridge, UK: Cambridge University Press. https://doi.org/10.1017/CBO9780511808678 
North, Douglass. 1981 Structure and Change in Economic History. New York, NY: Norton.

Olshan, Marc. 1994. “Amish Cottage Industries as Trojan Horse.” Pp. 133-46 in The Amish Struggle with Modernity edited by Donald Kraybill and Marc Olshan. Hanover, NH: University Press of New England.

O’Rourke, Kevin, and Jeffrey Williamson. 1999. Globalization and History: The Evolution of a Nineteenth-Century Atlantic Economy. Cambridge, MA: The MIT Press.

Peter, Karl. 1987. The Dynamics of Hutterite Society: An Analytical Approach. Edmonton, AB: University of Albert Press.

Peters, John. 1994. “Old Order Mennonite Economics.” Pp. 153-75 in Anabaptist/Mennonite Faith and Economics edited by Calvin Redekop, Cornelius Krahn, and Samuel Steiner. Lanham: University Press of America.

Redekop, Calvin. 1976. “Institutions, Power, and the Gospel.” Pp. 138-50 in Kingdom, Cross, and Community: Essays on Mennonite Themes in Honor of Guy F. Hershberger edited by John Burkholder and Calvin Redekop. Scottdale, PA: Herald Press.

—. 1994. "Mennonites and Economics: Concluding Analysis.” Pp. 373-82 in Anabaptist/Mennonite Faith and Economics edited by Calvin Redekop, Cornelius Krahn, and Samuel Steiner. Lanham: University Press of America.

Redekop, Calvin, Stephen Ainlay, and Robert Siemens. 1995. Mennonite Entrepreneurs. Baltimore, MD: Johns Hopkins University Press.

Redekop, Calvin, Cornelius Krahn, and Samuel Steiner. 1994. “Preface.” Pp. vii-x in Anabaptist/Mennonite Faith and Economics edited by Calvin Redekop, Cornelius Krahn, and Samuel Steiner. Lanham: University Press of America.

Redekop, Calvin, and Benjamin Redekop. 1996. Entrepreneurs in the Faith Community: Profiles of Mennonites in Business. Scottdale, PA: Herald Press.

Reschly, Steven. 2000. The Amish on the Iowa Prairie, 1840 to 1910. Baltimore, MD: Johns Hopkins University Press.

Richter, Rudolf. 2005. “The New Institutional Economics: Its Start, Its Meaning, Its Prospects.” The European Business Organization Law Review 6(2):161-200. https://doi.org/10.1017/S1566752905001618

Ryan, John. 1977. The Agricultural Economy of Manitoba Hutterite Colonies. Toronto, ON: McClelland and Stewart.

Schlabach, Theron. 2007. "The Historiography of Mennonites and Amish in America: Reflections on Past and Future.” Mennonite Quarterly Review 81(1):49-75. 
Séguy, Jean. 1973. "Religion and Agricultural Success: The Vocational Life of the French Anabaptists from the Seventheenth to the Nineteenth Centuries." Tranaslated by Michael Shank. Mennonite Quarterly Review 47(3):179-224.

Sharp, John. 2015. My Calling to Fulfill: The Orie O. Miller Story. Harrisonburg, VA: Herald Press.

Sprunger, Mary. 1994. "Dutch Mennonites and the Golden Age Economy: The Problem of Social Disparity in the Church.” Pp. 19-40 in Anabaptist/Mennonite Faith and Economics edited by Calvin Redekop, Cornelius Krahn, and Samuel Steiner. Lanham: University Press of America.

Steinmo, Sven. 2001. “The New Institutionalism.” In The Encyclopedia of Democratic Thought edited by Barry Clark and Joe Foweraker. London, UK: Routledge.

Swedberg, Richard. 2000. Max Weber and the Idea of Economic Sociology. Princeton, NJ: Princeton University Press.

—. 2008. "Die Neue Wirtschaftssoziologie und das Erbe Max Webers.” Pp. 45-61 in Handbuch der Wirtschaftssoziologie edited by Andrea Maurer. Wiesbaden, Germany: Verlag für Sozialwissenschaften. https://doi.org/10.1007/978-3-531-90905-9_3

Tank, Heide. 1979. Die Entwicklung der Wirtschaftsstruktur einer traditionellen Sozialgruppe: Das Beispiel der Old Order Amish in Ohio, Indiana und Pennsylvania, USA. Berlin, Germany: Selbstverlag des Geographischen Instituts der Freien Universität Berlin.

Thiessen, Janis. 2013. Manufacturing Mennonites: Work and Religion in Post-War Manitoba.

Toronto, ON: University of Toronto Press. https://doi.org/10.3138/9781442690332

- 2016. Not Talking Union: An Oral History of North American Mennonites and Labour. Montreal, Quebec: McGill-Queen's University Press.

Wallis, John Joseph. 2016. "The New Economic History and Beyond: The Scholarship of Douglass C. North.” The Journal of Economic History 76(3):937-47. https://doi.org/10.1017/S0022050716000851

Weber, Max. 1949. The Methodology of the Social Sciences. New York, NY: The Free Press. -. 2003[1958]. The Protestant Ethic and the Spirit of Capitalism: Translated by Talcott Parsons. Mineola: Dover Publications. 